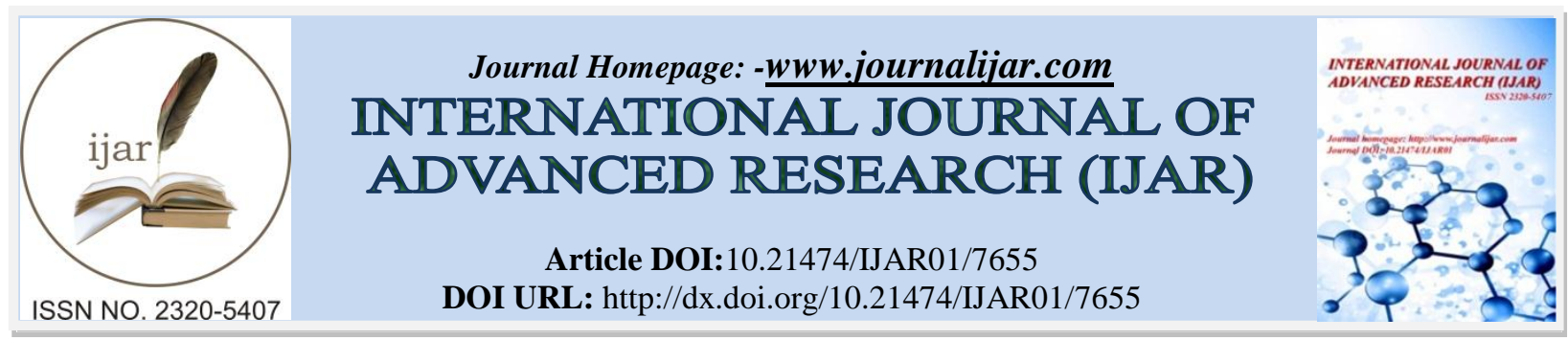

RESEARCH ARTICLE

\title{
DIVERSITY OF THE INDIGENOUS ARBUSCULAR MYCORRHIZAE FUNGI (AMF) IN THE RHIZOSPHERE OF CITRONELLA (Andropogon nardus L.) IN THE DRY LAND REGIONS IN WEST SUMATRA PROVINCE, INDONESIA.
}

\author{
Armansyah $^{1}$, Aswaldi Anwar ${ }^{1}$, Auzar Syarif ${ }^{2}$, Yusniwati dan ${ }^{2}$ and Rudi Febriamansyah' ${ }^{2}$.
}

1. Faculty of Agriculture, University of Andalas / Student of Study Program of Agricultural Science, Post Graduated Program, Andalas University, Pascasarjana Building, Limau Manis Padang. 25163. Indonesia. 2, Padang 25163, Indonesia.

2. Faculty of Agriculture, University of Andalas Padang Western Sumatra Indonesia.

\section{Manuscript Info}

Manuscript History

Received: 03 July 2018

Final Accepted: 05 August 2018

Published: September 2018

Keywords:-

Diversity, arbuscular, indigenous mycorrhizal fungi, rhizosphere,

\section{Abstract}

Arbuscular mycorrhizal fungi (AMF), are soil microbes that have the potential to increase yield and low productivity agricultural inputs. Independent AMF exploration will provide preliminary information about the diversity of species of spores from these fungi in crop rhizosphere. This information is very important to know that the use of AMF in the crop is more effective and efficient. Nearly $96 \%$ of crops are able to symbiosis with AMF. The aim of this study was to determine the diversity of indigenous $\mathrm{AMF}$ in the citronella rhizosphere. Soil samples were taken from 3 citronella crop locations randomly. The results of the study found 7 species of AMF indigenous, namely Glomus sp 1, Glomus sp 2, Acaulospora sp 1, Acaulospora sp 2, Acaulospora sp 3, Gigaspora sp 1 and Sclerocystis sp 1.

Copy Right, IJAR, 2018,. All rights reserved.

\section{Introduction:-}

Arbuscular mycorrhizal fungi (AMF), are soil microbes that have the potential to increase yield and low productivity agricultural inputs. Independent AMF exploration will provide preliminary information about the existence of spores from these fungi in crop rhizomes. This information is very important to know that the use of AMF in crops is more effective and efficient

Research that has been carried out, on various types of agricultural crops shows nearly $96 \%$ of AMF is able to colonize with root systems as one of the biological fertilizers (Smith and Read 2008). Arbuscular mycorrhizal fungi are obligate facultative, which requires host crops to breed. Spores will germinate if there is compatibility with the cropping system. Crop roots will produce exudates, including flavonoids. Flavonoids will be responded to by spores, if there is a match then the spores will germinate and infect the root system of the crop (Gosling et al., 2013)

The diversity of AMF in rhizosphere crops will have an ecological effect around the roots. Knowing the diversity of indigenous AMF in crop needs to be done because different combinations of host and AMF crops have different effects on morphology, nutritional status, symbiotic efficiency and gene expression patterns on symbiosis (Nadja F and Thomas B. 2010). 
The diversity of AMF in the world according to INVAM (2013) recorded around 250 species associated with crops that are spread from tropical to subtropical regions. According to Bearley (2012) In the general tropics, AMF is associated with almost all crops, except Dipterocarpaceae, because these crop groups are associated with ectomycorrhiza

Arbuscular mycorrhizal fungi can play a good role in a dry land where water availability is limited to crops. The connection of external hyphae from AMF is able to expand the absorption area of water and nutrients. The connection of external hyphae can develop further into the soil. While the roots of crop growth and development are limited. Dryland crops that are symbiotic with AMF will be able to grow and develop better.

The symbiosis of crops with AMF shows good results. The results research of Armansyah (2001) on gambir crop seeds aged 16 weeks after cropping, of the 3 types of AMF inoculated only Glomus manihatus types were more suitable than Acaulospora heterogama and Gigaspora roseae. Inoculation of Inoculation of $5 \mathrm{~g}$ of Glomus seeds can increase $141 \%$ seedling stem height, $148 \%$ seedling stem circle, increase the relative growth rate of $154 \%$ and $151 \%$ net assimilation rate. Likewise with the results of a study conducted by Husin et al., (2012) pine crop that was given mycorrhizae were able to absorb $243 \%$ more $\mathrm{P}, 86 \%$ more $\mathrm{N}$ and $75 \%$ more $\mathrm{K}$ when compared to nonmycorrhizae pine crop.

Citronella (Andropogon nardus L) is a crop that is cultivated in the dry land. This crop is one of the producers of essential oils which are included in the Gramineae family. The essential oil produced is better known as etheric oil, flying oil or essential oil. Citronella essential oil from Indonesia in the world of trade is called Citronellal Oil of Java because it comes from the island of Java from the Mahapengiri type.

The quality of Citronella essential oil is determined by the content of citronellal and geraniol. These compounds are important components to determine the quality of essential oils. If the two compounds are low in percentage, the selling value will decrease and not include the criteria for export. Citronellal and geraniol are raw materials for various types of industries, such as perfumes, cosmetics, pharmaceuticals and flavoring agents.

The cultivation of citronella in dry land is a challenge faced by the low ability of crop roots to absorb water and nutrients because the roots are fibers. The fiber root system only develops in the topsoil. Root systems like this are thought to have an impact on the low yield of citronella essential oil. Citronella smells about $0.8-1.0 \%$. This yield is very low compared to the yield of Patchouli oil yield 2.0 - 4.2\% (Yuhono and Sintha 2006), clove flowers 8.6\% (Henny et al., 2013), and kaffir lime leave 13.4\% (Safaatul and Prima 2010).

One effort to increase the yield of citronella essential oil, namely the use of indigenous AMF. Arbuscular mycorrhizal fungi are indigenous, have adaptability in host rhizosphere crops. The level of suitability of the AMF individual is higher than that introduced. The difference in the location of citronella cropping will result in differences in species diversity and indigenous AMF populations because it will be influenced by environmental factors. Therefore, to find out the diversity of individual AMF types, a study was conducted on three locations of citronella, namely Laiang, Balai Batu Sandaran and Simawang. This research is a preliminary study to obtain information on the diversity of citronella AMF. The results of the study will be used as the basis of the study to see the potential of individual AMF to increase the yield of citronella essential oil. This study aims to determine the diversity of mycorrhizal fungi in indigenous Arbuscular in citronella rhizosphere.

\section{Materials and Method:- Study Site and Sampling}

Soil samples taken from rhizosphere are citronella. Soil sampling in three locations of citronella corporations namely Laiang Solok, Balai Batu Sandaran Sawah Lunto and Simawang Tanah Datar. Laiang, District of Solok $480 \mathrm{~m}$ asl 100.32 E - 0.32 S 2. Balai Batu Sandaran, Kota Sawahlunto $785 \mathrm{~m}$ asl 100.47 E - 0.46 S 3. Simawang, District of Tanah Datar $600 \mathrm{~m}$ asl 100.28 E-0.28 S.

The topography of the three locations is bumpy and hilly. The three locations of the average rainfall are very low. Balai Batu Sandaran does not rain for almost 3 months. Laiang and Simawang rainfall conditions are almost the same, every month in the form of low-intensity drizzle rain. Citronella crops in the three locations use a monoculture pattern with a spacing of 1 x 1 meter. The type of citronella that is cultivated by the Mahapengiri type. 
Taking soil samples in the rhizosphere

Soil samples were taken from around the citronella crop about $10 \mathrm{~cm}$ from the clump, into $0-20 \mathrm{~cm}$ in each cropping area. The number of soil samples taken was 5 samples. Samples of soil that have been taken are put into a plastic bag that has been labeled. The soil samples that have been taken are air dried for 2 days before wet screening

\section{Extraction of AMF Spores}

Spore extraction of indigenous AMF from citronella soil samples was carried out using wet sieving and centrifuge methods according to the method of Brundrett et al., 1996. Filtering uses multilevel filters $(500 \mu \mathrm{m}, 300 \mu \mathrm{m}, 106$ $\mu \mathrm{m}, 53 \mu \mathrm{m}$, and $45 \mu \mathrm{m}$ ). The filter results are added with $60 \%$ glucose in a centrifuge tube. Then centrifuged at a speed of $2500 \mathrm{rpm}$ for 3 minutes. The centrifuge results are cleaned with water using a $45 \mu \mathrm{m}$ sieve. Then poured into Petri dish and then observed using a binocular microscope

\section{The diversity of individual AMF by counting.}

The number and type of indigenous AMF were observed after the screening of soil samples. The number of spores was determined by counting all individual AMF spores observed using a microscope.

Species wealth values are calculated using the formula (Odum, 1993) as follows

$\mathrm{D}_{\mathrm{MG}}=(\mathrm{S}-1) / \mathrm{Ln} \mathrm{N}$

Description :

$\mathrm{D}_{\mathrm{MG}}=$ Value of species wealth.

$\mathrm{S}=$ The number of types of AMF spores found.

Ln = Logaritma.

$\mathrm{N} \quad=$ The total number of AMF spores.

Species abundance values are calculated using the formula (Odum, 1993) as follows

$$
\begin{aligned}
& \mathrm{H}^{\prime}=-\Sigma(\mathrm{pi} \ln \mathrm{pi}) \\
& \mathrm{Pi}=\mathrm{ni} / \mathrm{N} \\
& \mathrm{H}^{\prime}=\text { Spore species diversity index. } \\
& \mathrm{Ni}=\text { Number of individuals in species }-\mathrm{i} . \\
& \mathrm{Ln}=\text { Logaritma. } \\
& \mathrm{N}=\text { The total number of AMF spores. }
\end{aligned}
$$

Evenness values are calculated using formulas

$$
\mathrm{E}=\mathrm{H}^{\prime} / \ln \mathrm{S}
$$

$\mathrm{E}=$ Evenness type index.

$\mathrm{H}^{\prime} \quad=$ Shanon - Wiener diversity index.

$\mathrm{S}=$ The number of types found.

\section{Results and Discussion:-}

The type and amount and frequency of the presence of indigenous AMF

The number of AMF types found in rhizosphere in 3 citronella spices were 7 species with 4 genera namely Glomus sp 1, Glomus sp 2, Acaulospora sp 1, Acaulospora sp 2, Acaulospora sp 3, Gigaspora sp 1and Sclerocystis sp 1 (Table 1).

Table 1:-The number and type and frequency of the presence of indigenous AMF in Laiang, Balai Batu Sandaran, and Simawang.

\begin{tabular}{|c|l|c|c|c|c|c|}
\hline \multirow{2}{*}{ No } & AMF type & \multicolumn{2}{|c|}{$\begin{array}{c}\text { Number of AMF spores per 50 grams of soil } \\
\text { sample }\end{array}$} & Total & \multirow{2}{*}{$\begin{array}{c}\text { Frequency of } \\
\text { existence } \\
(\%)\end{array}$} \\
\cline { 3 - 5 } & $\begin{array}{c}\text { Balai Batu } \\
\text { Sandaran }\end{array}$ & Laiang & Simawang & & \\
\hline 1 & Glomus sp 1 & 250 & 1667 & 50 & 1967 & 100 \\
\hline 2 & Glomus sp 2 & 250 & 933 & 100 & 1283 & 100 \\
\hline 3 & Acaulospora sp 1 & 217 & 1717 & 50 & 1984 & 100 \\
\hline 4 & Acaulospora sp 2 & 17 & 133 & 0 & 150 & 67 \\
\hline 5 & Acaulospora sp 3 & 50 & 467 & 0 & 517 & 67 \\
\hline 6 & Gigaspora sp 1 & 0 & 100 & 0 & 100 & 67 \\
\hline
\end{tabular}




\begin{tabular}{|l|l|c|c|c|c|c|}
\hline 7 & Sclerocystis sp l & 417 & 1667 & 83 & 2167 & 100 \\
\hline & Number of Spores & 1201 & 6684 & 283 & 8168 & \\
\hline & Number of species & 6 & 7 & 4 & & \\
\hline
\end{tabular}

The number of indigenous AMF species found in the rhizosphere citronella for each cropping area is not the same. Laiang the number of indigenous AMF types found more than the Balai Batu Sandaran and Simawang. There were 7 species found in Laiang while Sandaran and Simawang Stone Hall were 6 and 4. Of the 7 species of AMF independent 4 species of a frequency of existence $100 \%$ were found in the three citronella locations namely Glomus sp 1, Glomus sp 2, Acaulospora sp 1 and Sclerocystis sp 1. Based on this frequency analysis, the existence of these four species is very potential to be developed as a source of inoculant for citronella. Further investigation into the potential of the four species will be carried out at the next stage of the study.

Arbuscular mycorrhizal fungi with a frequency of $100 \%$ indicate that the AMF type has a good level of compatibility with citronella. Arbuscular mycorrhizal fungi can multiply in the citronella root system. There is a match between citronella root exudate and fragrance with AMF. Root exudate is a source of nutrition and stimulates AMF proliferation. According to Smith and Read (2008), crop root exudates can affect spore germination and hyphal growth. Root exudates according to Huang et al., (2014) produce organic acids, amino acids, and specific sugars that can stimulate the movement of microbial spores to reach the root surface.

Percentage density of each individual AMF species showed that 4 species of indigenous AMF whose frequency of existence was $100 \%$ were above 10\%. Of the 4 indigenous AMF species, Sclerocystis sp 1 shows a high percentage of density which is $26.53 \%$. While the lowest is Gigaspora sp 1 which is $1.22 \%$ (Figure 1)

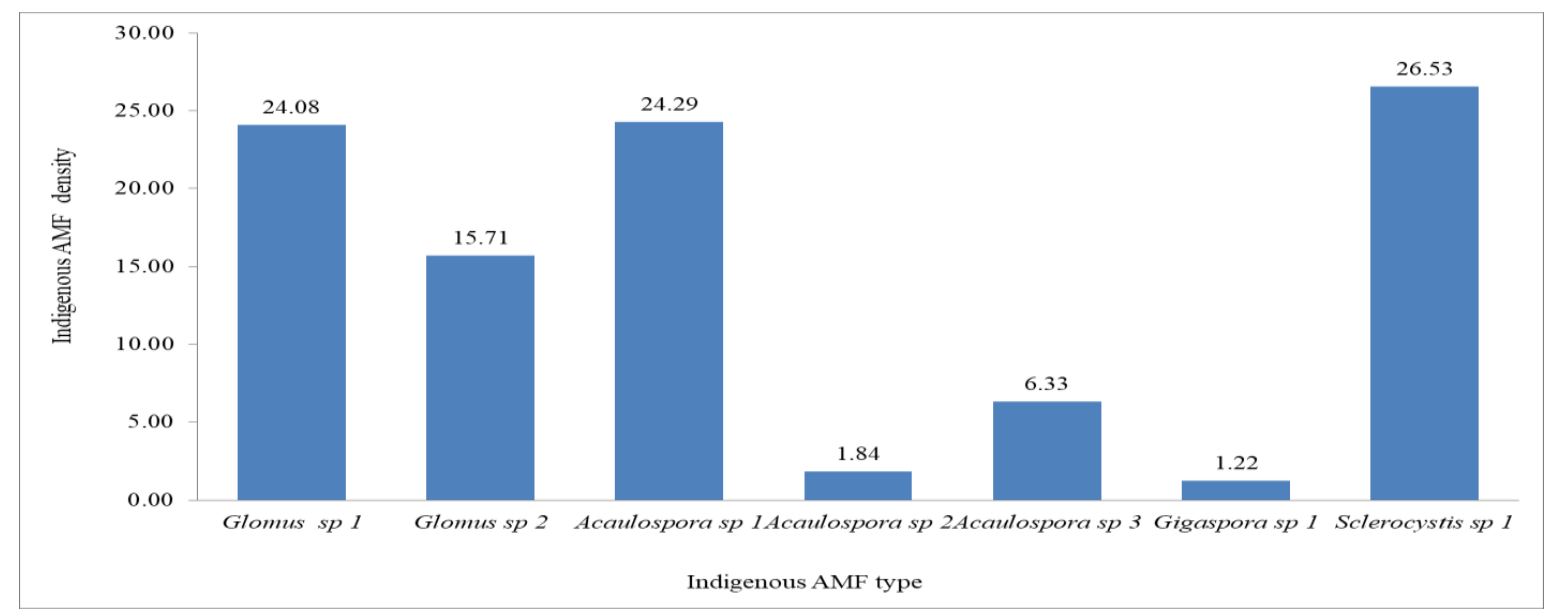

Figure 1:-Percentage density of each individual AMF species

Percentage density of indigenous AMF species explains how the relationship between certain indigenous AMF species with the total number of all indigenous AMF species found in rhizosphere citronella. The higher density percentage explained that the indigenous AMF species were more abundant in the citronella rhizosphere. The number of indigenous AMF species high in crop rhizosphere indicated that the indigenous AMF species had a good level of suitability with citronella. Root exudates released to rhizosphere according to Sugiyama and Yazaki (2012), can occur in pasisf diffusion and active excretion. The exudate can have an effect on the presence of micro soil organisms. In addition, direct and indirect root exudates according to Baetz (2016) affect the interaction of micorooragnism in the soil with crop root systems. Positive interactions will encourage an increase in the number of microorganisms in rhizosphere crops.

\section{Value of species wealth}

The value of species richness is information about the number of species of AMF found in the citronella area. AMF species richness values from the three areas of citronella are relatively the same, ranging from 0.53 to 0.71 (Figure 2). According to Barbour et al., (1987) the value of species richness can range from 0 - 7, with criteria: 0 - 2 (low), 2 - 3 (moderate), and> 3 (high). Thus the value of the wealth of AMF species in citronella cropations is low. 
Low AMF species richness in citronella areas is indicated because of the monoculture cropping system. Citronella in Laiang and Balai Batu Sandaran have been cultivated continuously for more than 10 years. This condition has an impact on the type of AMF that can breed in the citronella rhizosphere. The type of AMF that can breed, of course, which has a level of suitability with citronella. While citronella which is cultivated in Simawang is only 6 months. The citronella rhizosphere is still not stable, because the soil is only processed and newly croped with citronella.

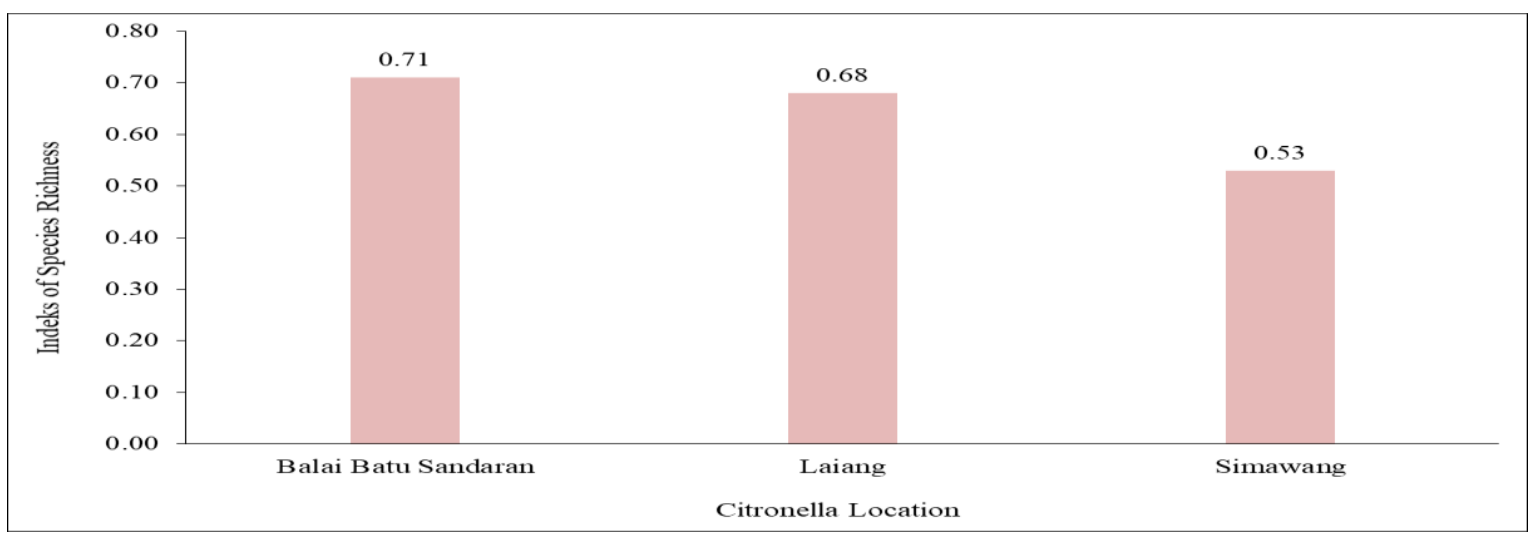

Figure 2:-AMF strength value in the citronella rhizosphere in the Balai Batu Sandaran, Laiang and Simawang fields.

\section{Spore species diversity index (H')}

Species abundance values explain the diversity of AMF species in the citronella rhizosphere. The abundance value of species from the three citronella areas is all above 1. The highest abundance value of species found in the Laiang area is 1.58. While the lowest found in Simawang area is 1.34. (Figure 3).

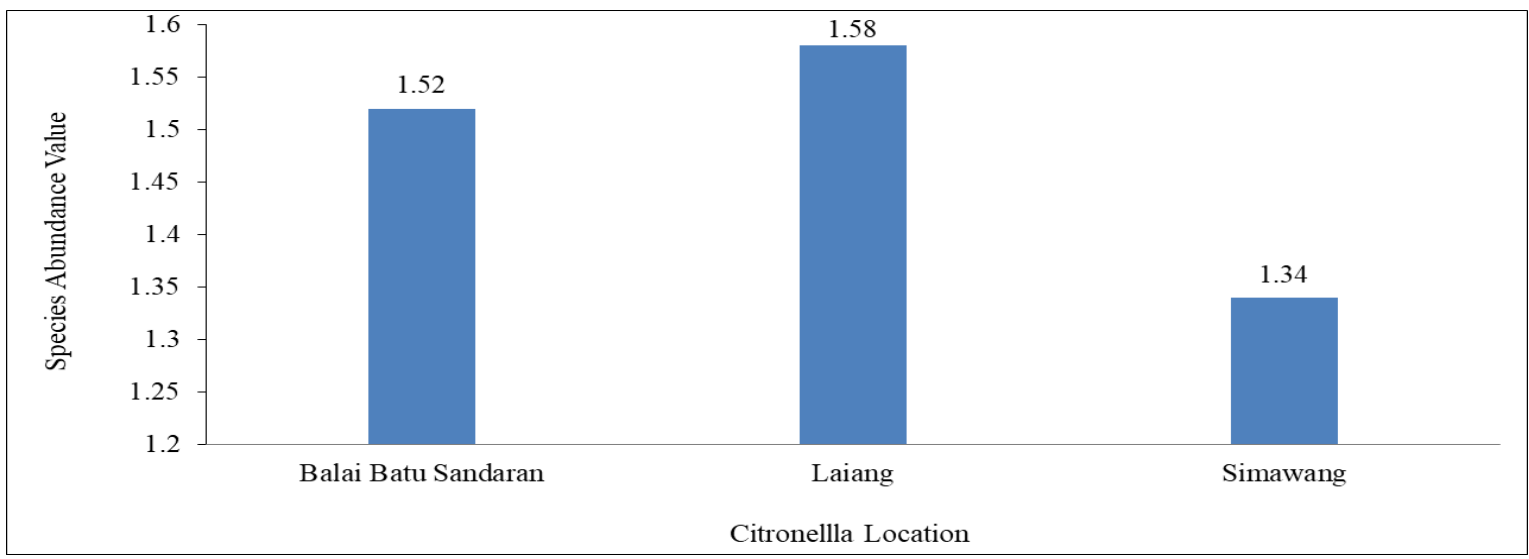

Figure 3:-Value of abundance of AMF species in the citronella rhizosphere in the Balai Batu Sandaran, Laiang and Simawang croping area

\section{Evenness type index (E)}

Evenness type value is a measure of balance between certain types of AMF and other types. Evenness value of the AMF type in the citronella area shows that the Simawang area has the highest value of 0.97. While the Laiang area has the lowest value of 0.81. The low evenness value of the AMF type in Laiang indicates that this area is dominated by certain types of AMF. Arbuscular mycorrhizal fungi on Laiang are dominated by Glomus sp 1, Glomus sp 2, Acaulospora sp 1 and Sclerocystis sp 1. The number of spores from the four types of AMF is more than 900 spores, while other types are less than 500 spores. Evenness value of Simawang regional type is higher compared to other regions because the number of spores of each type is almost the same, namely between 0-100 spores, there are no AMF spores which are more dominant than the other types. According to Ludwig and Reynolds (1988), the value of species equality is very determined by the number of species found in one community. 


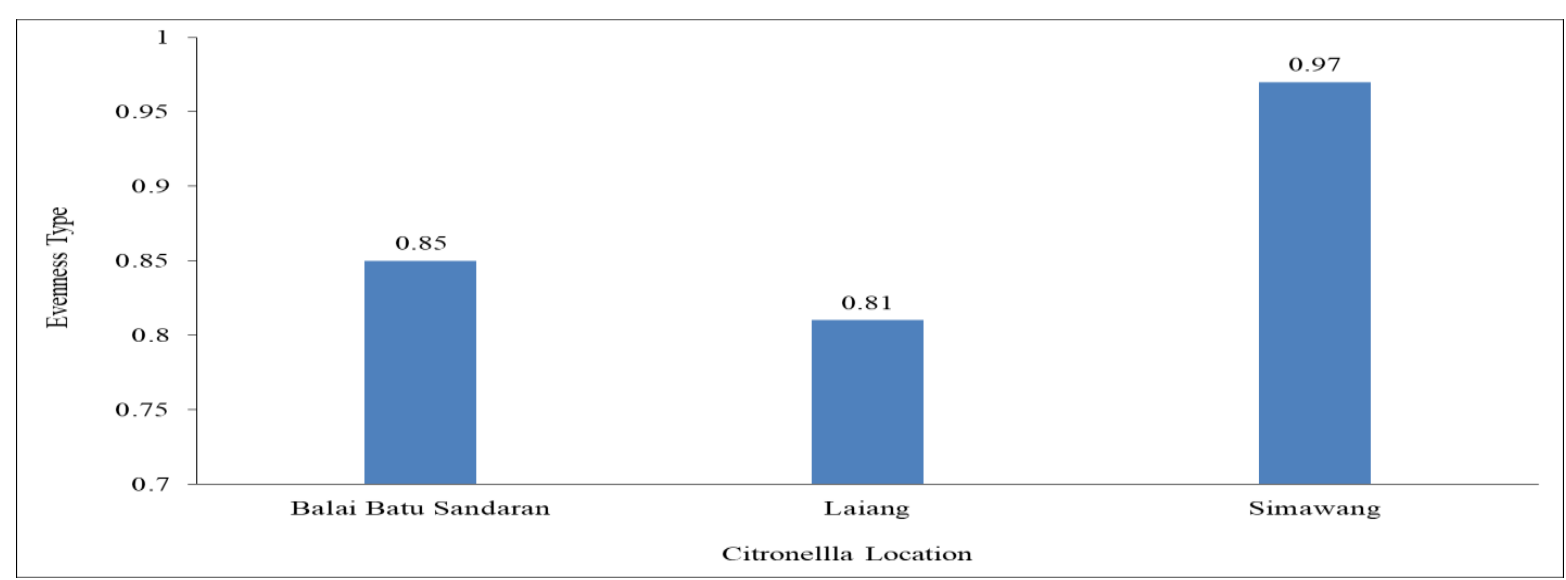

Figure 4:-Evenness value of indigenous AMF species in the citronella rhizosphere in the Balai Batu Sandaran, Laiang and Simawang fields

\section{Conclusion:-}

There were seven AMF species found in the rhizosphere in three citronella growing areas, namely Glomus sp 1, Glomus sp 2, Acaulospora sp 1, Acaulospora sp 2, Acaulospora sp 3, Gigaspora sp 1 and Sclerocystis sp 1.

\section{References:-}

1. Armansyah.2001. Dosage effectiveness test of several types of arbuscular mycorrhizal fungi on the growth of gambier plant seeds (Uncaria gambir Roxb). Tesis S2 PPS Unand. Padang.

2. Bearley FQ. 2012. Ecthomycorrhizal association of the Dipterocarpaceae. Biotropica. 4(5):637-648.

3. Brundrett M., N. Bougher, B. Dell, T. Grove, and N. Malajczuk. 1996. Working with mycorrhyzas in forestry and agriculture. Australian Centre for International Agricultural Research (ACIAR). Canberra, Australia. 374 pp

4. Huang, J.M. Chaparro, K.F. Reardon, R. Zhang, Q. Shen, J.M. Vivanco.2014.Rhizosphere interactions: root exudates, microbes, and microbial communities. Botany, 92 (2014), pp. 267-275

5. Gosling P, Mead A, Proctor M, Hammond J, Bending G (2013) Contrasting arbuscular mycorrhizal communities colonizing different host crops show a similar response to a soil phosphorus concentration gradient. New Phytol 198:546-556

6. Henny Prianto, Rurini Retnowati and Juswono. 2013. Isolation and characterization of dried clove flower oil (Syzigium aromaticum) resulting from steam distillation.. Student Journal, Vol. 1, No. 2, pp. 269275.Universitas Brawijaya Malang.

7. Husin, E.F., A. Syarif and Kasli. 2012. Mycorrhiza as a Supporter of Sustainable and Environmental-Based Agricultural Systems. Andalas University Press. 99 hal

8. Invam.2003.Internasional culture colection of arbuscular and vesicular mycorrhizal fungi.http://invam.caf.wvu.edu/mycinfo/taxonomy/classification.htm. 18 Agustus.2003.

9. Ludwig, J.A. and Reynolds, J.F. (1988) Statistical Ecology: A Primer on Methods and Computing. WileyInterscience Pub., New York.

10. Nadja Feddermann and Thomas Boller. 2010. Functional diversity in arbuscular mycorrhiza - the role of gene expression, phosphorous nutrition, and symbiotic efficiency.Fungal Ecology. Volume 3, Issue 1, February 2010, Pages 1-8.

11. Odum E.P.1993. Ecological basics. Indonesian Edition . Yogyakarta.Gajah Mada University Press. Hal 35 - 41

12. Safaatul Munawaroh and Prima Astuti Handayani. 2010. Extraction of Grapefruit Leaf Oil (Citrus hystrix D.C.) with Ethanol and N-Hexane Solvents. Technical Competency Journal Vol. 2, No.1, November. 2010.

13. Smith SE, and Read DJ. 2008. Mycorrhizal Symbiosis. Third Edition. New York: Academic.

14. Yuhono J.T. and Sintha Suhirman. 2006. Strategy to increase the yield and quality of oil in patchouli agribusiness. Research Institute for Medicinal and Aromatic Plants. litbang balittro. 